\title{
Genetic Diversity in Toona ciliata M. Roem., progenies using $D^{2}$ Analysis
}

\author{
K. Mohanraj, S. Umesh Kanna, K.T. Parthiban and K. Kumaran \\ Department Forest Biology and Tree Improvement, Forest College and Research Institute \\ TNAU, Mettupalayam-641 301, India \\ E-mail: palanimohan07@gmail.com
}

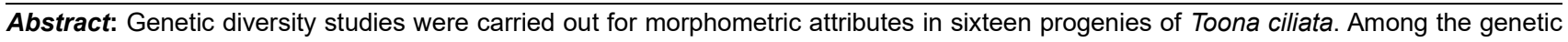
resources of Toona ciliata a multivariate analysis was carried out using $D^{2}$ clustering technique and classified sixteen progenies into five clusters. Cluster II revealed the maximum intra-cluster distance. The maximum inter cluster distance was found between clusters III and IV which exhibits a higher genetic distance between Toona ciliata progenies. Volume index (81.66 percent) contributed the highest genetic divergence among the growth characters, followed by basal diameter and plant height.
\end{abstract}

Keywords: Toona, Growth attributes, Genetic divergence, D² clustering

Toona ciliata comes under the family is called Meliaceae, which is native to India, Australia, Indo-china peninsula, Pacific Islands and southern china. It is commonly known as Australian red cedar or Chinese mahogany (Yang et al 2020). It is a shade bearer and tree attains $30 \mathrm{~m}$ height with well spreading crown. The wood of Toona is more valued because of its colour, durability and timber quality (Zhan et al 2019). The current forest and tree cover of the country is 21.67 per cent (71.22 million ha) and 2.89 per cent (9.51 million ha), respectively. The annual harvest of the timber from the forest declined from 10 million $\mathrm{m}^{3}$ in the 1970's to 4 million $\mathrm{m}^{3}$ in 1990 and currently it is 3 million $\mathrm{m}^{3}$. The annual timber production of TOF is 85 million $\mathrm{m}^{3}$ in 2020 . The total wood demand of India is 153 million $\mathrm{m}^{3}$ in 2020 and the productivity of wood is only 60 million $\mathrm{m}^{3}$ (Shrivastava and Saxena 2017). To meet the demand of large sized wood, the policy of importing wood has been liberalized since the 1990s. Total import of round wood and sawn wood logs was 6 million cubic meters from 2014-15 to 2019-20. India imports all type of wood except pulp, paper and news prints (Rai and Chakrabarti 2001). The importing of wood increases day by day so to meet out the wood demand we need to identify and screen alternate fast growing multipurpose trees. Toona ciliata is the one among the best fast growing and alternative species which could be used as raw material for wood based industries.

The study of genetic diversity becomes more valuable in tree improvement programme because it increases the chances of recovering superior genotypes (Zobel and Talbert 1984). To assess the genetic divergence among the genotypes $D^{2}$ statistics has been considered as one of the most powerful technique. $D^{2}$ analysis, the superior group or individual may legitimately be used to raise profitable plantations to meet industrial wood demand. None of the studies have indicated about genetic diversity in Toona ciliata against this backdrop the current investigation have been carried out.

\section{MATERIAL AND METHODS}

Progenies evaluation trail was established at Forest College and Research Institute, Mettupalayam with 16 which were collected from elected Candidate Plus trees (CPTs) from 3 different states viz., Tamil Nadu, Karnataka and Punjab. Toona ciliata progenies collected form CPTs were planted in a Randomized Block Design (RBD) with three replications at an espacement of $4 \mathrm{~m} \times 4 \mathrm{~m}$. The details of the actual locations of the sixteen chosen candidate plus trees were presented in the Table 1.

Plant height: The plant height was measured in centimeters with the help of measuring tape from ground level to the tip of the stem.

Basal diameter: The Basal diameter was measured in centimeters with the help of digital caliper at the base of the stem (near the ground level).

Volume index: After estimating the plant height and basal diameter, the volume index was calculated using the formula below.

$$
\begin{gathered}
\text { V.I. }=(\text { Basal diameter })^{2} \times \text { Height }(\mathrm{cm})(\text { Hatchell } 1985, \\
\text { Manavalan 1990) }
\end{gathered}
$$

Estimation of genetic diversity: The data were resolved 2 
months interval after planting in Toona ciliata progenies for evaluation of genetic diversity.

Determination of genetic divergence: Genetic divergence was calculated using $\mathrm{D}^{2}$ statistics design. The progenies were clustered using $D^{2}$ statistical results. The parameters used in the $D^{2}$ statistics were plant height, collar diameter and volume. The mean squares and mean products between groups and within components at the progeny level were estimated using one way analysis of variance, covariance and level of significance. A variance - covariance was calculated and essential condensation was performed to obtain the linear function for transforming character mean values $(x)$ to set of independent variables (uncorrected mean) value $(y)$.

To calculate the $D^{2}$ square values the variation between any two mean values for any pair of progenies was squared and added. Collective $\mathrm{D}^{2}$ square values in all possible combinations of progeny were determined for each character.

$$
\begin{gathered}
y_{1}=x_{1} \\
y_{2}=x_{2}-a_{2} x_{1} \\
y_{3}=x_{3}-a_{32} y_{2}-a_{31} y_{1} \\
y p=y p-a_{p p-1} y_{p-1} \ldots \ldots . . a_{1} y_{1}
\end{gathered}
$$

Where,

$\mathrm{X} 1=$ Normalized variables

$$
\begin{gathered}
a_{i j}=b_{i j} / v(y j) S<-1 \\
v\left(y_{j}\right)=\lambda \sum a_{(i j)} b_{i j}-b_{i j}=\lambda_{i j}-1 / a t b t \\
\lambda_{i j}=\text { Covariance of } i \text { and } j_{t}-j_{i}
\end{gathered}
$$

All probable $n(n-1) / 2 D^{2}$ values were calculated by adding the sum of the differences between two corresponding 'y' values for two progenies at a time.

Estimation of clusters or grouping: The genotypes were classified into different clusters using the "GENERES" statistical packages based on the root of $D^{2}$ values, by using Tocher's method as recommended by Rao (1952).

Tocher's method: Tocher's method used to cluster all values. Rao (1952)

$$
\begin{aligned}
& n(n-1) \\
& \ldots \ldots . . . D^{2} \\
& 2
\end{aligned}
$$

Estimation of Average intra and inter cluster distance: Once clustering was achieved, the intra and inter cluster associations were arranged, and the communal associations among clusters and their distances were represented. The following formula was used to calculate the average intra cluster distances.

$$
D=D^{2} / n
$$

The average inter cluster divergences were calculated

\begin{tabular}{|c|c|c|c|c|c|}
\hline Sources & District & State & Name of sources & Latitude & Longitude \\
\hline Katteri, Nilgiri hills & Nilgiri & Tamil Nadu & FCRI TC 1 & $11^{0} 33^{\prime} 31^{\prime \prime} \mathrm{N}$ & $076^{0} 79^{\prime} 7 " \mathrm{E}$ \\
\hline Aravenu, Kotagiri stretch & Nilgiri & Tamil Nadu & FCRI TC 2 & $11^{\circ} 32^{\prime} 43^{\prime \prime} \mathrm{N}$ & $076^{\circ} 95^{\prime} 58^{\prime \prime} \mathrm{E}$ \\
\hline Nadugani, Gudulur division TC1 & Nilgiri & Tamil Nadu & FCRI TC 3 & $11^{\circ} 47^{\prime} 21 " \mathrm{~N}$ & $076^{\circ} 41^{\prime} 31^{\prime \prime E}$ \\
\hline Nadugani, Gudulur division TC2 & Nilgiri & Tamil Nadu & FCRI TC 4 & $11^{\circ} 44^{\prime} 59 " \mathrm{~N}$ & $076^{\circ} 41^{\prime} 27^{\prime \prime} \mathrm{E}$ \\
\hline Pandalur, Gudulur division & Nilgiri & Tamil Nadu & FCRI TC 5 & $11^{0} 33^{\prime} 71^{\prime \prime} \mathrm{N}$ & $076^{\circ} 93^{\prime} 66^{\prime \prime} E$ \\
\hline Devala, Gudular division & Nilgiri & Tamil Nadu & FCRI TC 6 & $11^{0} 33^{\prime} 52 " \mathrm{~N}$ & $076^{\circ} 92^{\prime} 50 " \mathrm{E}$ \\
\hline Choondi, Gudulur division & Nilgiri & Tamil Nadu & FCRI TC 7 & $11^{\circ} 32^{\prime} 40^{\prime \prime} \mathrm{N}$ & $076^{\circ} 92^{\prime} 60 " \mathrm{E}$ \\
\hline Thadiyankudisai TC4 & Dindigul & Tamil Nadu & FCRI TC 8 & $10^{\circ} 29^{\prime} 44 " \mathrm{~N}$ & $077^{0} 70^{\prime} 50 " \mathrm{E}$ \\
\hline Thadiyankudisai TC3 & Dindigul & Tamil Nadu & FCRI TC 9 & $10^{\circ} 29^{\prime} 27 " \mathrm{~N}$ & $077^{0} 70^{\prime} 19^{\prime \prime} \mathrm{E}$ \\
\hline Pongalarmedu, Thadiyankudisai beat & Dindigul & Tamil Nadu & FCRI TC 10 & $10^{\circ} 31^{\prime} 98 " \mathrm{~N}$ & $077^{\circ} 65^{\prime} 40 " E$ \\
\hline Sampallioothu, Thadiyankudisai beat & Dindigul & Tamil Nadu & FCRI TC 11 & $10^{\circ} 31^{\prime} 03^{\prime \prime} \mathrm{N}$ & $077^{0} 65^{\prime} 29 " E$ \\
\hline Kodagu & Kodagu & Karnataka & FCRI TC 12 & $12^{0} 14^{\prime} 43^{\prime \prime} \mathrm{N}$ & $075^{\circ} 93^{\prime} 95 " \mathrm{E}$ \\
\hline Ponampet & Kodagu & Karnataka & FCRI TC 13 & $12^{0} 14^{\prime} 47^{\prime \prime} \mathrm{N}$ & $075^{\circ} 94^{\prime} 51 " \mathrm{E}$ \\
\hline Ludhiana TC5 & Ludhiana & Punjab & FCRI TC 14 & $30^{\circ} 90^{\prime} 10^{\prime \prime} \mathrm{N}$ & $075^{\circ} 80^{\prime} 71 " \mathrm{E}$ \\
\hline Ludhiana TC6 & Ludhiana & Punjab & FCRI TC 15 & $30^{\circ} 90^{\prime} 10^{\prime \prime} \mathrm{N}$ & $075^{\circ} 80^{\prime} 71 " \mathrm{E}$ \\
\hline TC 02 & Ludhiana & Punjab & FCRI TC 16 & $30^{\circ} 90^{\prime} 10^{\prime \prime} \mathrm{N}$ & $075^{\circ} 80^{\prime} 71^{\prime \prime E}$ \\
\hline
\end{tabular}
by taking into account all possible $D^{2}$ values between the records of the two clusters, where $D^{2}$ was the sum of distances between all possible combinations of progeny included in a cluster. Following that, the genetic distance ' $D$ ' between the clusters was calculated by taking the square root of the average $D^{2}$ values.

Statistical analysis: GENERES statistical package new version was used to determine the genetic diversity analysis Kanna et al (2019).

Table 1. Details of Toona ciliata progenies and their location 


\section{RESULTS AND DISCUSSION}

The biometric parameters viz., plant height, collar diameter, and volume index were recorded at four different growth phases viz., Initial, 60 DAP (Days after Planting), 120 DAP and 180 DAP in sixteen progenies of Toona ciliata. The data were examined for genetic diversity, and the results are shown below.

Genetic divergence: For all positive pairs, $D^{2}$ values were computed. The biometric characteristics of plant height, collar diameter and volume index were used to examine divergence and clustering. The sixteen Toona ciliata progenies were divided into 5 genetically divergent clusters.

Intra and inter cluster average distance: Table 2 depicts the average intra and inters cluster values for each of the five clusters. Cluster II revealed the highest average intra cluster value (1.546), while Cluster IV and V had the lowest (0.00). Cluster IV and III showed the highest inter-cluster value (2.941). The lowest inter-cluster value was found between clusters I and II (1.693).

According to Tewari and Singhania, (1994), the plant diversity refers to the variety and variability within an environment. To improve all kind of tree species, breeders are constantly engaged in the effective selection of desirable parents with high genetic variability so that the individuals with desirable character combinations can be selected achieved. The majority of plant species especially forestry species have very long rotation period, out crossing mechanism and huge heterozygosity which evolved a amount of natural mechanisms to keep up heterozygosity and intra specific variations. Such genetic mechanisms, combined with natural environment variations, appear to have contributed to forest species particularly in trees being among the most genetically variable organisms studied to date (Libby WJ, 1987). Traditionally the genetic diversity in trees has been done through provenance testing, enzyme electrophoresis and molecular techniques using DNA (Kertadikara and Prat 1995, Mandal and Gupta 1996, Williams et al 1990).

Cluster components: $D^{2}$ analysis classified sixteen progenies into five clusters. Table 3 exhibits the cluster members and the number of progenies in each cluster. In the five clusters, the cluster II showed highest number of progenies which is resolved with nine progenies, namely FCRI TC 3, FCRI TC 4, FCRI TC 5, FCRI TC 7, FCRI TC 8, FCRI TC 9, FCRI TC 10, FCRI TC 11, and FCRI TC 12. Cluster I had three progenies, namely FCRI TC 1, FCRI TC 2, and FCRI TC 6, Whereas Cluster III had only two progenies, namely FCRI TC 14, and FCRI TC 16. Clusters IV and V each had only one progeny, FCRI TC 13 and FCRI TC 15, respectively.
Cluster mean for each morphometric character was calculated and it is shown in table 4 . Cluster IV had the highest cluster mean for plant height $(556.667 \mathrm{~cm})$, while cluster II had the lowest cluster mean for plant height $(145.620 \mathrm{~cm})$. Cluster $\mathrm{V}$ performed best in terms of collar diameter $(4.898 \mathrm{~cm})$, followed by cluster I $(4.794 \mathrm{~cm})$, and cluster II exhibited the worst performance $(3.822 \mathrm{~cm})$. In terms of volume index, cluster I had the highest cluster mean value $\left(4876.568 \mathrm{~cm}^{3}\right)$ and cluster II had the lowest $(2410.375$ $\mathrm{cm}^{3}$ ). The main goal of the clustering method is to divide the pool of observations into many subgroups in order to achieve homogeneity within and between the subgroups. Genetic divergence is an important tool in the field of plant breeding for achieving desirable qualities in trees and plants. The genetic diversity estimates the degree of diversity that existed between the genotypes that were chosen.

The $D^{2}$ clustering method was used in Toona ciliata to segregate the sixteen progenies into five clusters; cluster II

Table 2. Intra and Inter cluster values of Toona ciliata progenies based on biometric attributes

\begin{tabular}{lccccc}
\hline Cluster & 1 & 2 & 3 & 4 & 5 \\
\hline I & 1.693 & 2.092 & 2.005 & 2.563 & 1.278 \\
II & & 1.546 & 1.704 & 2.941 & 1.777 \\
III & & & 0.679 & 2.546 & 1.050 \\
IV & & & & 0.000 & 2.271 \\
V & & & & & 0.000 \\
\hline
\end{tabular}

Table 3. Toona ciliata cluster pattern details based biometric attributes

\begin{tabular}{lcl}
\hline Cluster No & $\begin{array}{c}\text { No of } \\
\text { progenies }\end{array}$ & Members \\
\hline I & 3 & FCRI TC 1, FCRI TC 2, FCRI TC 6 \\
II & 9 & FCRI TC 3, FCRI TC 4, FCRI TC 5, FCRI \\
& & TC 7, \\
& & FCRI TC 8, FCRI TC9, FCRI TC 10, \\
& 2 & FCRI TC 11, FCRI TC 12 \\
III & 1 & FCRI TC 14, FCRI TC 16 \\
IV & 1 & FCRI TC 13 TC 15 \\
V & &
\end{tabular}

Table 4. Toona ciliata cluster mean values based on biometric characters

\begin{tabular}{lccc}
\hline Cluster & Plant height $(\mathrm{cm})$ & $\begin{array}{c}\text { Basal diameter } \\
(\mathrm{cm})\end{array}$ & $\begin{array}{c}\text { Volume index } \\
\left(\mathrm{cm}^{3}\right)\end{array}$ \\
\hline I & 197.056 & 4.754 & 4876.568 \\
II & 145.620 & 3.822 & 2410.375 \\
III & 154.917 & 4.585 & 3388.913 \\
IV & 556.667 & 4.657 & 4085.778 \\
V & 181.417 & 4.898 & 4626.987 \\
\hline
\end{tabular}


exhibited the most progenies (nine). The results stand similar with the findings of Kanna et al (2019) classified thirty Ailanthus excelsa progenies into nine clusters. Cluster IV had most progenies (10 progenies) of the nine clusters. In Neolamarckia cadamba 20 progenies were divided into five clusters. Cluster II had demonstrated the greatest intracluster distance. The greatest inter-cluster distance was measured between clusters III and V (Parthiban et al 2019). According to Singhdoha et al. (2017), sixty CPTs of Acacia nilotica were distributed among seven different clusters, with cluster I had the most (14 CPTs), followed by cluster V. The average intra-cluster distance was found to be greatest in cluster I, followed by cluster IV and cluster II, while the intercluster distance ranged from 2.681 to 5.734 , with cluster I and VII having the greatest distance. The genetic diversity studies classified twenty Neolamarckia cadamba progenies into five clusters, with cluster III having the greatest intra -cluster distance. Clusters I and IV had the greatest intercluster distance (Shree et al 2018). In groundnut (Arachis hypogaea) 93 genotypes were divided into eight clusters. Cluster VI has the most members (18), followed by cluster VII and I. cluster $V$ had the highest intra cluster values, followed by cluster IV Dhakar et al (2017). In sorghum (Sorghum bicolor L.) 20 genotypes were classified into four distinct clusters. The maximum (6) and lowest (4) number of genotypes were found in clusters I and IV respectively. Clusters II and IV (150.99) and cluster III and IV (150.99) had the greatest and smallest inter cluster distances respectively Navya et al (2021).

In the present study, it was observed that progenies from various locations were grouped together to form a single major cluster, as seen in cluster II, and thus the degree of divergence was not dependent on geographic location. The above-mentioned findings also confirmed an earlier report of Kanna et al (2019), Parthiban et al (2019), Shree et al (2018), Singhdoha et al (2017), Sangram and Keerthika (2013). The presence of divergent provenances in the same cluster in nature may be attributed to factors other than geographic distribution being responsible for their genetic relationship. The intra and inter cluster recorded values indicated that IV and $\mathrm{V}$ had no intra cluster because they only had one progeny.

\section{Contribution of Characters towards Genetic Divergence}

Table 5 explained the percentage and number of times each character ranked first, along with their genetic divergence. The volume index contributed the most to divergence $(81.667 \%)$, followed by the collar diameter (15.833\%). Contribution of plant height was found to have the lowest to the genetic divergence $(2.500 \%)$. The findings are in corroboration with the findings of Singhdoha et al (2017) in
Table 5. Percentage wise contribution of each character towards genetic divergence in Toona ciliata progenies based on biometric attributes

\begin{tabular}{lcc}
\hline Character & No. of first rank & Contribution (\%) \\
\hline Plant height & 3 & 2.5000 \\
Basal diameter & 19 & 15.8333 \\
Volume index & 98 & 81.6667 \\
Total & 120 & 100 \\
\hline
\end{tabular}

Acacia nilotica, Parthiban et al. (2019) in Neolamarckia cadamba; Kanna et al (2019) in Ailanthus excelsa. Volume index, along with other biometric characteristics, contributed to genetic divergence between the progenies tested, which could be due to the existence of broad genetic base (Kanna et al. 2019). Based on previous research and current findings, the Volume index for genetic divergence could be used as an index for the Toona ciliata tree improvement programme.

\section{CONCLUSION}

The $D^{2}$ analysis classified sixteen Toona ciliata genetic resources into five clusters. Cluster II had the most progenies among the five clusters. Cluster II determined the greatest intra-cluster distance. Cluster IV had the greatest inter-cluster distance, indicating a greater genetic distance between Toona ciliata progenies. Among the growth characters, volume index contributed the greatest percentage to genetic divergence, followed by collar diameter and plant height played the smallest role in the divergence.

\section{REFERENCES}

Chavan Sangram and Keerthika A 2013. Genetic variability and association studies among morphological traits of Leucaena leucocephala (Lam.) de Wit. genetic resources. Research Journal of Agriculture and Forestry Sciences 1(8):23-29.

Dhakar TR, Hemlata S and Prashant B 2017. Genetic diversity analysis in groundnut (Arachis hypogaea L.) genotypes using $\mathrm{D}^{2}$ statistics. Indian Journal of Ecology 44(Special Issue 4): 175181.

Kanna SU, Krishnakumar N and Jailani KMMAK 2019. Genetic divergence studies in Ailanthus excelsa using $\mathrm{D}^{2}$ Analysis. International Journal of Environment and Climate Change 21: 416-424

Kertadikara AWS and Prat D 1995. Genetic structure and mating system in teak (Tectona grandis L.) provenances. Silvae Genetica 44(2-3): 104-110.

Libby WJ 1987. Genetic resources and variation in forest trees. In: Improving vegetatively propagated crops. Academic Press, USA. 199-209.

Mandal AK and Gupta BN 1996. Isozyme differentiation in two subspecies of Acacia nilotica. Proceeding of Indian National Science Academy, Part B. Biological Sciences 61(1): 39-42.

Navya Y, Singh PK and Sushma B 2021. Genetic variability and diversity analysis for yield attributing and biochemical parameters of sorghum (L.) Sorghum bicolor genotypes. Indian Journal of Ecology 48(3): 853-858. 
Parthiban KT, Thirunirai-Selvan $\mathrm{R}$, Palanikumaran $\mathrm{B}$ and Krishnakumar N 2019. Variability and genetic diversity studies on Neolamarckia cadamba genetic resources. Journal of Tropical Forest Science 31(1): 90-98.

Rai SN and Chakrabarti SK 2001. Demand and supply of fuelwood and timber in India. Indian Forester 127(3): 263-279.

Rao CR 1952. Advanced statistical methods in biometric research.

Shree MP, Krishnakumar N and Parthiban KT 2018. Genetic diversity and relationships of Neolamarckia cadamba (Roxb.) Bosser progenies through cluster analysis. Tropical Plant Research 5(1): 107-115.

Shrivastava S and Saxena AK 2017. Wood is good: But, is India doing enough to meet its present and future needs. Centre for Science and Environment, New Delhi.

Singhdoha A, Dhillon RS and Johar V 2017. Estimation of genetic diversity among superior CPTs of Acacia nilotica. International

Received 12 October, 2021; Accepted 10 January, 2022
Journal of Current Microbiology and Applied Sciences 6(10): 1197-1202.

Tewari SK and Singhania DL 1994. Character association and path analysis in grain sorghum. Sorghum Newsletter 27: 16-17.

Williams JGK, KubelikAR, Livak KJ, Rafalski JAand Tingey SV 1990. DNA polymorphisms amplified by arbitrary primers are useful as genetic markers. Nucleic Acids Research 18: 6531-6535.

Yang W, Dan Y and Xinzhi L 2020. Genetic diversity of Toona ciliata populations based on SSR markers. Journal of Resources and Ecology 11(5): 466-474.

Zhan X, Li P, Hui W, Deng Y, Gan S, Sun Y and Deng X 2019. Genetic diversity and population structure of Toona ciliata revealed by simple sequence repeat markers. Biotechnology and Biotechnological Equipment 33(1): 214-222.

Zobel B and Talbert J 1984. Applied forest tree improvement. John Wiley \& Sons, 525p. 